\title{
Assessing the Effect of Irrigation with Reclaimed Water Using Different Irrigation Techniques on Tomatoes Quality Parameters
}

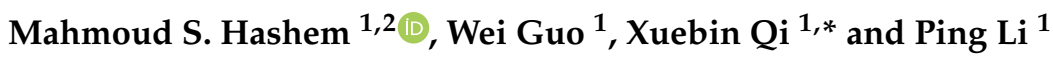 \\ 1 Farmland Irrigation Research Institute, Chinese Academy of Agricultural Sciences, Xinxiang 453003, China; \\ mahmoudsabry375@gmail.com (M.S.H.); guowei1124@163.com (W.G.); liping05@cass.cn (P.L.) \\ 2 Agricultural Research Center, Agricultural Engineering Research Institute (AEnRI), Giza 256, Egypt \\ * Correspondence: qxb6301@sina.cn
}

Citation: Hashem, M.S.; Guo, W.; Qi, X.; Li, P. Assessing the Effect of Irrigation with Reclaimed Water Using Different Irrigation Techniques on Tomatoes Quality Parameters. Sustainability 2022, 14, 2856. https:// doi.org/10.3390/su14052856

Academic Editors: Mohamed Mattar and Jan Hopmans

Received: 19 December 2021 Accepted: 22 February 2022 Published: 1 March 2022

Publisher's Note: MDPI stays neutral with regard to jurisdictional claims in published maps and institutional affiliations.

Copyright: (c) 2022 by the authors. Licensee MDPI, Basel, Switzerland This article is an open access article distributed under the terms and conditions of the Creative Commons Attribution (CC BY) license (https:// creativecommons.org/licenses/by/ $4.0 /)$

\begin{abstract}
As the most important resource for life, water has been a central issue in the international agenda for several decades. Yet, the world's clean freshwater supply is steadily decreasing due to climate change and extensive agricultural water demand for irrigated lands. Therefore, in addition to rational water use, we should use non-traditional water resources like Reclaimed Wastewater (RW). The present experiment was carried out in China over three years $(2017,2018$, and 2019) to study the effects of two types of water qualities (reclaimed wastewater (RW) and clean water (CW)), two types of irrigation methods (Full irrigation (FI) and alternate partial root-zone irrigation (APRI)), and two types of irrigation techniques (Furrow irrigation (FUI) and subsurface drip irrigation (SDI)) on the main tomato fruit quality parameters. The APRI treatments obtained $70 \%$ of the FI irrigation water volume. The irrigation treatments of this study were: (1) SDI with APRI; (2) SDI with FI; (3) FUI with APRI; and (4) FUI with FI. These treatments were under RW and CW. Thus, the experiment consisted of eight treatments. The tomato fruit quality parameters studied were vitamin C (VC), total acidity (TA), protein content (PC), and total soluble sugar content (TSS). The results reveal that many measurements under reclaimed water (RW) had the highest values compared with clean water (CW), except in protein content (PC). The vast majority of values measured for PC under CW were slightly greater than the values under RW. Moreover, the results reveal that tomato quality in many measurements under APRI treatments increased compared with FUI. The statistical analysis generally shows that the fruit quality parameters were not significantly $(p>0.05)$ affected by the interaction between the irrigation treatments. In conclusion, the treatment SDI-APRI under RW can be an efficient irrigation method to reduce the consumption of clean water. Additionally, SDI-APRI offers a safe option because the physical contact between the wastewater, crops, and the farmers is minimized compare with the FUI treatment.
\end{abstract}

Keywords: reclaimed wastewater; tomato fruit quality subsurface drip irrigation; alternate partial root-zone irrigation

\section{Introduction}

The world's supply of clean fresh water is steadily decreasing. In many areas around the world, the water demand exceeds the supply. The world's populations and water demand continue to increase, leading to scarcity of freshwater. [1-3]. Irrigation is considered the main user of freshwater because it withdrawals approximately $80 \%$ of the total freshwater [3] with 15\% extra withdrawal expected by the year 2030 [4,5], which will create water crises in many regions around the world. Therefore, this highlights the necessity for reusing wastewater as an essential water source for agriculture [6]. The reuse of Reclaimed wastewater (RW) could be one of the essential alternatives to develop and manage the water resource $[7,8]$, particularly in arid areas, as it expresses different renewable water resources [9]. China is considered the largest producer of wastewater. Approximately 108.16 billion cubic meters of wastewater are being released yearly in 
China $[10,11]$. Therefore, treating some of these huge quantities of wastewater and using it in irrigation will save huge amounts of fresh water. Wastewater reuse for irrigation of agriculture has higher acceptability compared to its re-use in other fields $[8,12,13]$.

Tomatoes (Lycopersicon esculentum Miller) are considered the most important vegetable globally and has high water requirements. Tomato irrigation demands an understanding of both irrigation systems and scheduling approaches. More efficient irrigation techniques can save irrigation water without reducing quality or yield. Many researchers around the world have demonstrated the positive effects of RW irrigation on crop growth and product [14-16]. According to several studies, irrigation using treated wastewater (TW) has no negative effects on plants and the food chain [17-19]. Ref. [20] stated that the agro-industrial TW considered another alternative irrigation source for industrial tomato production. Ref. [21] indicated that there was a positive influence in the yield and growth of tomatoes that were irrigated with TW comparing with groundwater irrigation, suggesting that TW irrigation can probably replace groundwater irrigation.

TSS, Vitamin C, lycopene, protein content and titratable acidity contents are commonly considered as fruit-quality-determining properties in tomato [22]. Many methods have been used by researchers to determine these quality parameters [23-29]. Many researchers demonstrated that there is no significant effect on vegetable quality (vitamin C, soluble sugar, coarse ash, amino acid content, and nitrate levels) when using RW irrigation [30]. Ref. [31] pointed out that RW irrigation enhances taste indexes of tomatoes, such as titratable acidity and soluble sugar of fruit to a certain extent.

Refs. [32,33] mentioned that TW irrigation enhanced most of the tomato quality parameters slightly compared to freshwater due to the high availability of nutrients.

According to [34], irrigation systems can be classified into two categories, both of which are used for RW irrigation, as follows: (1) surface irrigation and (2) pressurized irrigation. Border and furrow irrigations are the most commonly used methods in surface irrigation systems [35]. Drip irrigation is the most suitable irrigation system in the case of using saline or reclaimed water [36,37]. According to [38], subsurface drip irrigation (SDI) provided more trustworthy yield and growth data than surface drip irrigation. Almost one and a half times higher tomato yield was obtained under drip irrigation than under furrow irrigation along with saving 30 percent of irrigation water [39].

Ref. [40] wrote that SDI is the most suitable irrigation technique for using wastewater because it has proven to be effective in declining the number of pathogens in irrigation water and limiting their presence on the soil's surface.

Alternate partial root-zone irrigation (APRI) is an irrigation technique that cuts some irrigation amount from the full irrigation requirement of crops and generally increases the productivity of water. These reduction amounts depend on the type of plant as well as the growing season [41]. Ref. [42] stated that compared to the full irrigation, APRI treatment improved tomato fruit quality. Deficit irrigation methods can enhance tomato fruit quality in terms of VC and acidity when compared to full irrigation $[43,44]$.

This study hypothesized that the use of RW using some irrigation techniques will not affect the quality of tomatoes and will lead to a reduction in the use of fresh water in irrigation. Therefore, this study aims to assess the effect of RW and clean water (CW) on tomato quality factors under furrow irrigation (FUI) and SDI systems with full irrigation (FI) and APRI in arid climatic conditions.

\section{Materials and Methods}

\subsection{Experimental Site}

The experiment was carried out over three years $(2017,2018$, and 2019) in greenhouses at the Agriculture Water and Soil Environment Field Science Research Station, Chinese Academy of Agricultural Sciences $\left(35^{\circ} 19^{\prime} 0^{\prime \prime} \mathrm{N}, 113^{\circ} 53^{\prime} 0^{\prime \prime}\right.$ E, elevation $\left.73.2 \mathrm{~m}\right)$, Xinxiang City, Henan Province, People's Republic of China, in the continental monsoon climate area of the temperate zone. The annual mean air temperature of the site is $14.1 \mathrm{C}$. The site has $588.8 \mathrm{~mm}$ of precipitation annually and $2398.8 \mathrm{~h}$ of sunlight per year, and a 210-day 
frost-free period. The soil properties including organic matter, extractable phosphorus, and total nitrogen were $19.90,0.02467$, and $0.85 \mathrm{~g} \mathrm{~kg}^{-1}$, respectively. The soil texture was silty clay loam, Bulk density was $1.40 \mathrm{~g} \mathrm{~cm}^{-3}$, and soil $\mathrm{pH}$ was 8.00 . In this study, we selected a research area irrigation with RW from Luotuo Wan Reclamation Plant in Xinxiang city $\left(35^{\circ} 15^{\prime} 09^{\prime \prime} \mathrm{N}, 113^{\circ} 55^{\prime} 05^{\prime \prime} \mathrm{E}\right.$, and altitude $\left.73.2 \mathrm{~m}\right)$, undergoing an anaerobic-anoxic-oxic denitrification biofilter and ozone oxidation process.

The purpose of this experiment was to study the impact of two types of water quality, two types of irrigation methods, and two types of irrigation techniques on the main quality parameters of tomato fruit (Lycopersicon esculentum L.). The two types of water qualities were RW and CW, the two types of irrigation methods were FI and APRI, and the two types of irrigation techniques were FUI and SDI.

The plots employed RW and tap-water irrigation. The reclaimed water was taken from the Camel Bay sewage treatment plant after secondary treatment, a source of municipal sewage. The typical factors of RW met the National Standard for Farmland Irrigation Water Quality (GB5084-2005) [45]. The quality of RW and tap water are shown in Table 1.

Table 1. RW and tap water Quality.

\begin{tabular}{cccccccccc}
\hline Index & $\mathbf{p H}$ & $\begin{array}{c}\mathbf{C d} \\
\left(\mathbf{m g} \cdot \mathbf{L}^{-\mathbf{1}}\right)\end{array}$ & $\begin{array}{c}\mathbf{C u} \\
\left(\mathbf{m g} \cdot \mathbf{L}^{-\mathbf{1}}\right)\end{array}$ & $\begin{array}{c}\mathbf{P b} \\
\left(\mathbf{m g} \cdot \mathbf{L}^{-\mathbf{1}}\right)\end{array}$ & $\begin{array}{c}\mathbf{Z n} \\
\left(\mathbf{m g} \cdot \mathbf{L}^{-\mathbf{1}}\right)\end{array}$ & $\begin{array}{c}\mathbf{T N} \\
\left(\mathbf{m g} \cdot \mathbf{L}^{-\mathbf{1}}\right)\end{array}$ & $\begin{array}{c}\mathbf{T P} \\
\left(\mathbf{m g} \cdot \mathbf{L}^{-\mathbf{1}}\right)\end{array}$ & $\begin{array}{c}\mathrm{EC} \\
\left(\mathbf{d s} \cdot \mathbf{m}^{-\mathbf{1}}\right)\end{array}$ & $\begin{array}{c}\mathrm{COD} \mathbf{M n} \\
\left(\mathbf{m g} \cdot \mathbf{L}^{-\mathbf{1}}\right)\end{array}$ \\
\hline Reclaimed water & 7.84 & 0.0021 & 0.035 & 0.026 & 0.772 & 29.57 & 1.95 & 2.06 & 17.6 \\
\hline Clean water & 7.32 & 0.0004 & 0.006 & 0.005 & 0.016 & 4.63 & 0.23 & 1.62 & 7.2 \\
\hline
\end{tabular}

\subsection{Irrigation Treatments}

The irrigation treatments were: (1) SDI with APRI; (2) SDI with FI; (3) FUI with APRI; and (4) FUI with FI. These treatments were under RW and CW, so the experiment consisted of eight treatments. The APRI treatments obtained $70 \%$ of the FI irrigation water volume. Each treatment was replicated three times. The statistical design used was a Completely Random Block Design (CRBD). The experimental unit number was 24 units. All irrigation water of treatments was applied either from aside as in FI treatment or from both sides as in APRI treatment.

In the SDI treatments, drip irrigation lines were laid at the centers of crop rows and separated by a $0.7-\mathrm{m}$ distance in the experimental FI treatments plots. On the other hand, in the APRI treatments plots, each row of tomato had two lateral lines with a distance of 0.4 between them and with a nested shape for the emitters. The distance between the treatments was $0.75 \mathrm{~m}$, as demonstrated in Figure 1. To achieve a long-term APRI effect on ABA signaling and leaf gas exchange in the tomato crop, irrigation with the treatment of APRI was shifted from one side of the plants to the other every 7 days [46].

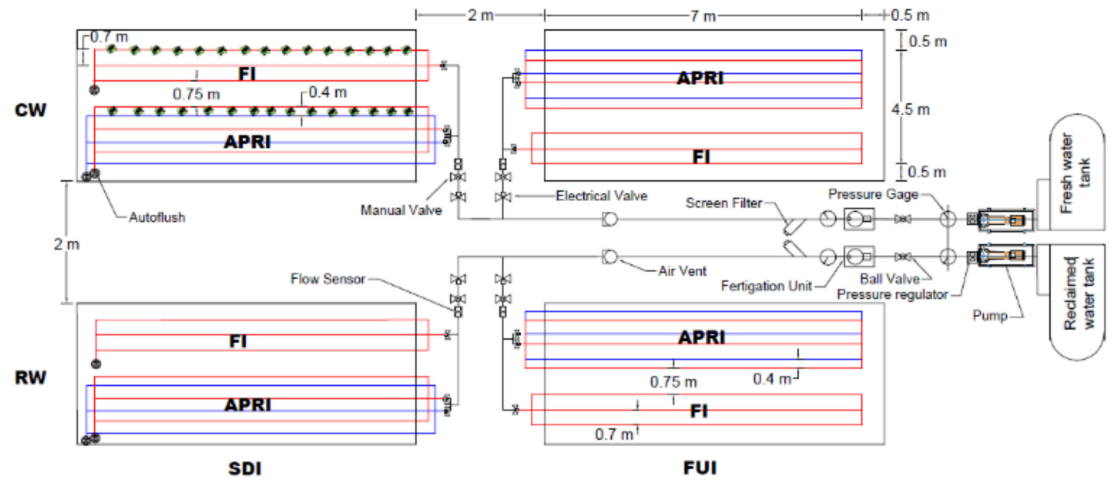

Figure 1. Experiment layout. CW and RW are Fresh water and Reclaimed water. DSI and FUI are Subsurface drip irrigation and Furrow irrigation. FI and APRI are Full irrigation and alternate partial root-zone irrigation. 
Based on the climatic data received from the meteorological station on the site, the water irrigation requirement was calculated as potential crop evapotranspiration using the ETo FAO Penman-Monteith equation [47] (Equation (1)) after adapting its parameter to the greenhouse climate conditions [48] (Equations (2)-(5)), and Kc, as shown in Equation (6). Then, the daily crop water requirement (CWRd) can be calculated using the Equation (6) [48]:

$$
\mathrm{ET}_{\mathrm{O}}=\frac{0.408 \Delta\left(\mathrm{R}_{\mathrm{n}}-\mathrm{G}+\mathrm{y} \frac{900}{\mathrm{t}_{\mathrm{mean}}+273} \mathrm{u}_{2}\left(\mathrm{e}_{\mathrm{s}}-\mathrm{e}_{\mathrm{a}}\right)\right.}{\Delta+\mathrm{y}\left(1+0.3 \mathrm{u}_{2}\right)}
$$

where $\mathrm{ET}_{\mathrm{O}}$ is the reference evapotranspiration $\left(\mathrm{mm} \mathrm{day}^{-1}\right) ; \Delta$ is the slope of saturation vapor pressure curve $\left(\mathrm{kPa}^{\circ} \mathrm{C}^{-1}\right)$; $\mathrm{Rn}$ is the net radiation at the crop surface $\left(\mathrm{MJ} \mathrm{m}^{-2} \mathrm{day}^{-1}\right)$; $\mathrm{G}$ is the soil heat flux density $\left(\mathrm{MJ} \mathrm{m}{ }^{-2} \mathrm{day}^{-1}\right)$; $\mathrm{y}$ is the psychrometric constant $\left(\mathrm{kPa}{ }^{\circ} \mathrm{C}^{-1}\right)$. $\mathrm{U}_{2}$ is the wind speed at $2-\mathrm{m}$ height $\left(\mathrm{m} \mathrm{s}^{-1}\right) ; \mathrm{T}$ is the mean daily air temperature at 2-m height $\left({ }^{\circ} \mathrm{C}\right)$; $\mathrm{e}_{\mathrm{s}}$ is the mean Saturation vapor pressure $(\mathrm{kPa})$; $\mathrm{e}_{\mathrm{a}}$ is the actual vapor pressure $(\mathrm{kPa})$.

$$
\begin{gathered}
\mathrm{T}_{\text {maxi }}=\mathrm{T}_{\text {maxo }}+4 \\
\mathrm{~T}_{\text {mini }}=\mathrm{T}_{\text {mino }}+2 \\
\mathrm{~T}_{\text {meani }}=\left(\mathrm{T}_{\text {maxi }}+\mathrm{T}_{\text {mini }}\right) / 2 \\
\text { Rsi }=\mathrm{Rs} \times \mathrm{t}
\end{gathered}
$$

where $T_{\text {maxo }}$ and $T_{\text {mino }}$ are the maximum and minimum temperatures outside the greenhouse. $\mathrm{T}_{\text {maxi }}$ and $\mathrm{T}_{\text {mini }}$ are the maximum and minimum temperatures inside the greenhouse. $\mathrm{T}_{\text {meani }}$ is the mean temperature inside the greenhouse. $\mathrm{Rs}_{\mathrm{i}}$ is the incoming global radiation, Rs is the outside global radiation, and $t$ is the transmittance of the greenhouse $(0.6-0.7$ for single plastic film covered greenhouses).

$$
\mathrm{ET}_{\mathrm{C}}=\mathrm{K}_{\mathrm{C}} \times \mathrm{ET}_{\mathrm{o}}
$$

where $\mathrm{ET}_{\mathrm{C}}$ is crop evapotranspiration $\left(\mathrm{mm}^{\text {day }}{ }^{-1}\right)$, and $\mathrm{K}_{\mathrm{C}}$ is crop coefficient.

The Kc for all growth stages of the tomato was taken from FAO-56.

$$
\mathrm{CWR}_{\mathrm{d}}=\mathrm{ET}_{\mathrm{C}}\left(1+\mathrm{l}_{\mathrm{i}}\right) \mathrm{A}_{\mathrm{Crop}} / \mathrm{A}_{\mathrm{G}}
$$

where $l_{i}$ is the loss factor for irrigation (0.03-0.1 for drip irrigation systems) and $A_{C r o p} / A_{G}$ is the ratio of the crop-covered area to the greenhouse floor area ( 0.9 for vegetables).

Fertilizer application, disease, insect, pest control, and other common cultural practices were implemented.

\subsection{Fruit Quality Characteristics}

Tomato crop was harvested many times every year. We collected the fruits manually from each line and weighed them to find the fresh weight of fruit $\left(\mathrm{Mg}_{\text {hectare }}{ }^{-1}\right)$ per each treatment. The tomato fruit quality parameters that were studied in this experiment were Vitamin C (VC), Total Acidity (TA), Protein Content (PC), and Total Soluble Sugar Content (TSS).

Throughout the harvest, five ripe fruits were sampled from the third-fourth trusses, representing each sub-plot for analysis of the fruit quality (VC ( $\left.\mathrm{mg} \mathrm{g}^{-1}\right)$, TA (\%), PC (mg $\left.100 \mathrm{~g}^{-1}\right)$, TSS (\%)). An extract was obtained by blending and filtering the flesh of each fruit sample. The VC ( $\mathrm{mg} \mathrm{g}^{-1}$, as ascorbic acid) of tomato extracted was determined using the 2.6 dichlorophenol-indophenol dye [49]. Ten grams of extracted juice was carefully mixed with $50 \mathrm{~mL}$ of distilled water to determine TA. Then, the $\mathrm{pH}$ of the mixture was adjusted with $0.1 \mathrm{~N} \mathrm{NaOH}$ until it reached 8.1.

To estimate TA as a percentage of citric acid equivalents in the fruit juice, the amount of sodium hydroxide applied to the solution was multiplied by a correction factor of 
0.064 [50]. The content of TSS (\%) was also estimated by using the following standard analysis methods (AOAC, 1999) [51]. The PC estimation was done using the Coomassie brilliant blue method [52].

\subsection{Statistical Analysis of the Data}

The statistical analysis of the present study's measured data was conducted using the SPSS software (IBM, Armonk, New York, NY, USA). The data were subjected to a multivariate analysis of variance (MNOVA). The MNOVA was conducted to compare the main effects of irrigation water qualities (CW and RW), irrigation methods (FI and APRI), and irrigation techniques (FUR and SDI), as well as their interaction effects on VC, TA, PC, and TSS. The Tukey test at $p<0.05$ was applied to find any significant difference between the means of irrigation treatments.

\section{Results and Discussion}

\subsection{Fresh Fruit Yield}

Fresh fruit yield per hectare (FW) for the different irrigation treatments throughout the three years is shown in Figure 2. Generally, the highest value of FW was obtained under RW throughout the three years. FW in 2017 (first year) ranged from 143.84 to $113.17 \mathrm{Mg} \mathrm{ha}^{-1}$ under RW, while it was from 117.54 to $103.20 \mathrm{Mg} \mathrm{ha}^{-1}$ under CW. The values of FW in the second year ranged from 126.40 to $103.05 \mathrm{Mg} \mathrm{ha}^{-1}$ under RW, while it was 111.13 to $94.86 \mathrm{Mg} \mathrm{ha}^{-1}$ under CW. In the third year, it ranged from 124.32 to $101.75 \mathrm{Mg} \mathrm{ha}^{-1}$ under RW, and from 98.17 to $79.83 \mathrm{Mg} \mathrm{ha}^{-1}$ under CW (Figure 2). The highest value was obtained under the SDI-FI, SDI-APRI, FUI-FI, and FUI-APRI, respectively, under RW and CW (Figure 2).

The results illustrate that the FW values under SDI-FI were more increased under RW than the values under SDI-APRI by $5.56 \%, 6.91 \%$, and $4.32 \%$ in first year, second year, and third year, respectively. However, this increase is not significant $(p>0.05)$ in the first and third years. Moreover, under both RW and CW, the FW values under FUI-FI were increased compared to the values under FUI-APRI throughout the three years, but this increase is not significant $(p>0.05)$.

The analysis of variances in the three years of the experimental period showed a significant effect $(p<0.05)$ of irrigation water qualities, irrigation methods, and irrigation techniques on the yield throughout the three years. In addition, there was a significant effect $(p>0.05)$ of the interaction between the experimental factors on the yield throughout the first and second years. Table 2 summarizes the results of the three-year analysis of variances on tomato quality parameter values across the experimental factors. Table 2 shows that the means of the yield under RW were higher than those under CW in all three years. Moreover, the means under FI were higher than under APRI. The same was the case under SDI compared to FU.

These results agree with the findings of $[49,53]$. They pointed out that the marketable yield under FI treatment gave the highest values compared with APRI. Ref. [54] observed that the highest tomato fruit yield was obtained under the full irrigation treatment, and they attributed that to exceeding the soil water content under full irrigation compared with deficit irrigation treatments. Ref. [55] reported that the highest marketable tomato yields were observed with full irrigation and decreasing irrigation rate. One can suppose that the higher fresh weight of FI fruits resulted from a longer ripening period that allowed a higher accumulation of water in these fruits compared to deficit irrigation fruits [56]. Ref. [57] concluded that the total tomato yield increased linearly with the seasonal irrigation depth and ETa. Similar findings on relationships between tomato fruit yields to irrigation depth or Eta were also illustrated [58-60]. These results were in agreement with the findings of [61] who pointed out that the total fresh mass of fruit was not affected by the regime treatments.

The increase in the yield under RW is in agreement with many researchers [15,62,63], who stated that crop production can considerably increase under RW. Ref. [64] reported that tomatoes under irrigation with TW achieved higher yields than plants irrigated with 
tap water. This increase in production can be because the RW consider a steady water source that can supply a large amount of nutrients $[65,66]$. Moreover, the result agreed with Ref. [67] who assessed the impacts of using RW and CW on soybean and maize growth, and they revealed that the yield of soybean and maize under TW treatment was clearly improved. Ref. [68] stated that under TW irrigation, the yield production of corn was increased, and they attributed this rise to the soil's physical characteristics improvement and enhanced nutrient uptake.

The present study results show that the highest yield under the three years was companied with SDI compared to FUI, both under CW and RW. This result is consistent with [69] who conducted a study to assess the impact of using TW with different irrigation systems on tomato, and they reported that the maximum yield of tomato was gained under drip irrigation treatments compared with other irrigation systems, which may result in a better soil moisture and increased content of the available nitrogen in the root zone. Moreover, this may be due to SDI reducing weed and grass growth and limiting the leaching of plant nutrients down in the soil [70]. Ref. [71] stated that the largest amounts of nutrients elements were recorded under SDI compared with surface irrigation.

2017
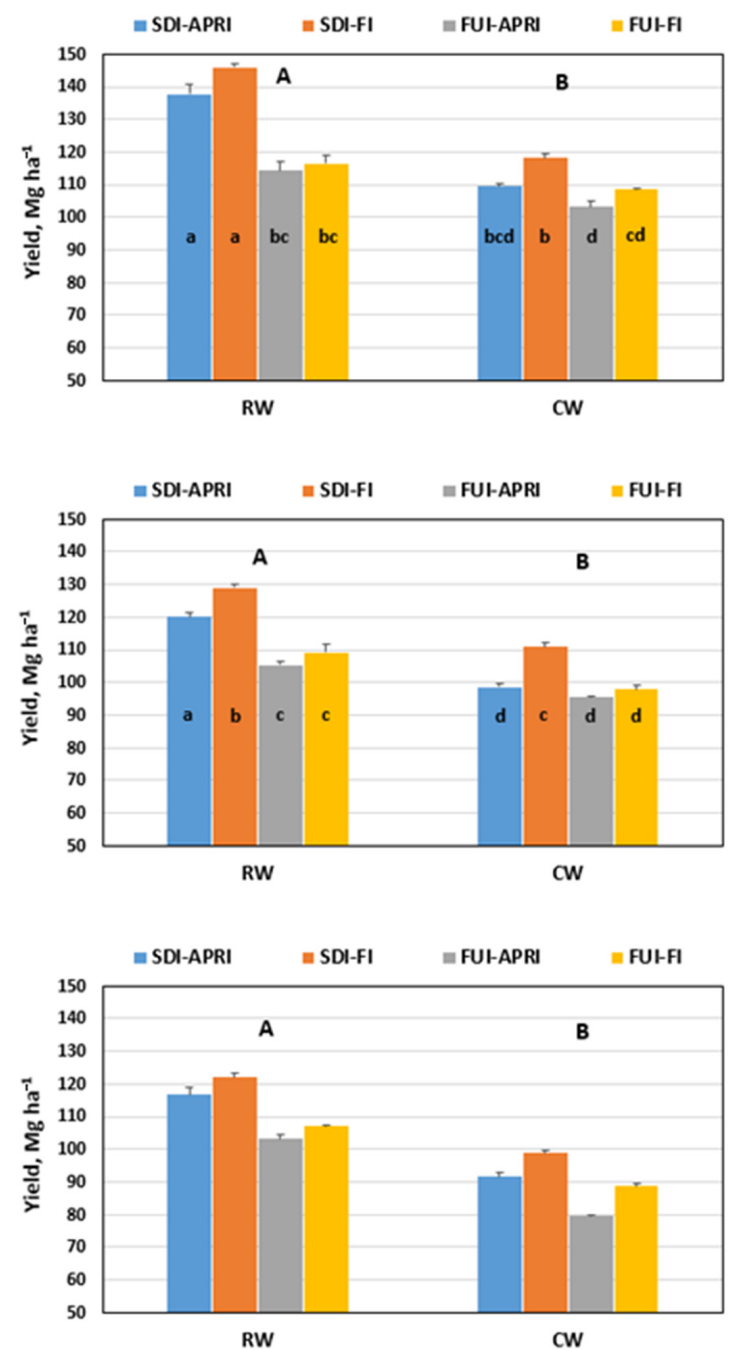

Figure 2. Fresh fruit yield $\left(\mathrm{Mg} \mathrm{ha}^{-1}\right)$ for the different irrigation treatments in tomatoes for the three years. The different capital letters on the top of the figure represented significant differences between water types at $p<0.05$. Different letters within columns revealed significant differences between irrigation treatments at $p<0.05$. Bars give the means \pm standard error of the mean $(n=3)$. RW: reclaimed water, CW: clean water, SDI: subsurface drip irrigation, APRI: alternate partial rootzone irrigation, FI: full irrigation, FUI: furrow irrigation. 
Table 2. Analysis of variances on the effect of water qualities, irrigation methods, irrigation techniques, and their interaction on tomato yield and quality parameters in the three years.

\begin{tabular}{|c|c|c|c|c|c|c|c|c|c|c|c|c|c|c|c|}
\hline \multirow{2}{*}{ Factor } & \multicolumn{3}{|c|}{$\begin{array}{c}\text { Content of Vitamin C } \\
(\mathrm{mg} / \mathrm{g})\end{array}$} & \multicolumn{3}{|c|}{$\begin{array}{c}\text { Total Acidity } \\
(\%)\end{array}$} & \multicolumn{3}{|c|}{$\begin{array}{l}\text { Protein Content } \\
(\mathrm{mg} / 100 \mathrm{~g})\end{array}$} & \multicolumn{3}{|c|}{$\begin{array}{c}\text { Content of soluble Sugar } \\
(\%)\end{array}$} & \multicolumn{3}{|c|}{$\begin{array}{c}\text { Yield } \\
\left(\mathrm{Mg} \mathrm{ha}^{-1}\right)\end{array}$} \\
\hline & $\begin{array}{l}\text { 1st } \\
\text { Year }\end{array}$ & $\begin{array}{l}\text { 2nd } \\
\text { Year }\end{array}$ & $\begin{array}{l}\text { 3rd } \\
\text { Year }\end{array}$ & $\begin{array}{l}\text { 1st } \\
\text { Year }\end{array}$ & $\begin{array}{l}\text { 2nd } \\
\text { Year }\end{array}$ & $\begin{array}{l}\text { 3rd } \\
\text { Year }\end{array}$ & 1st Year & $\begin{array}{l}\text { 2nd } \\
\text { Year }\end{array}$ & $\begin{array}{l}\text { 3rd } \\
\text { Year }\end{array}$ & $\begin{array}{l}\text { 1st } \\
\text { Year }\end{array}$ & $\begin{array}{l}\text { 2nd } \\
\text { Year }\end{array}$ & $\begin{array}{l}\text { 3rd } \\
\text { Year }\end{array}$ & 1st Year & $\begin{array}{l}\text { 2nd } \\
\text { Year }\end{array}$ & $\begin{array}{l}\text { 3rd } \\
\text { Year }\end{array}$ \\
\hline \multicolumn{16}{|l|}{ Water Type } \\
\hline RW (Reclaimed Wastewater) & $0.103 \mathrm{~b}$ & $0.210 \mathrm{~b}$ & $0.222 \mathrm{a}$ & $2.538 \mathrm{a}$ & $1.429 \mathrm{a}$ & $0.559 \mathrm{a}$ & $12.101 \mathrm{~b}$ & $39.986 \mathrm{~b}$ & $51.348 \mathrm{~b}$ & $1.562 \mathrm{a}$ & $3.310 \mathrm{a}$ & $4.128 \mathrm{~b}$ & $128.66 \mathrm{a}$ & $115.87 \mathrm{a}$ & $112.27 \mathrm{a}$ \\
\hline CW (Clean water) & $0.111 \mathrm{a}$ & $0.273 \mathrm{a}$ & $0.232 \mathrm{a}$ & $2.485 \mathrm{a}$ & $1.389 \mathrm{a}$ & $0.560 \mathrm{a}$ & $15.915 \mathrm{a}$ & $42.014 \mathrm{a}$ & $56.802 \mathrm{a}$ & $1.467 \mathrm{~b}$ & $3.297 \mathrm{a}$ & $4.866 \mathrm{a}$ & $109.86 \mathrm{~b}$ & $100.71 \mathrm{~b}$ & 89.66 b \\
\hline $\begin{array}{c}p \text {-value } \\
\text { Irrigation Methods }\end{array}$ & 0.000 & 0.000 & 0.114 & 0.202 & 0.347 & 0.879 & 0.000 & 0.037 & 0.003 & 0.013 & 0.832 & 0.000 & 0.000 & 0.000 & 0.000 \\
\hline FI (Full irrigation) & $0.104 \mathrm{~b}$ & $0.241 \mathrm{a}$ & $0.215 \mathrm{~b}$ & $2.497 \mathrm{a}$ & $1.388 \mathrm{a}$ & $0.540 \mathrm{~b}$ & $14.586 \mathrm{a}$ & $42.204 \mathrm{a}$ & $50.967 \mathrm{~b}$ & $1.465 \mathrm{~b}$ & $3.187 \mathrm{~b}$ & $4.476 \mathrm{a}$ & $122.29 \mathrm{a}$ & $111.79 \mathrm{a}$ & $104.12 \mathrm{a}$ \\
\hline $\begin{array}{l}\text { APRI (Alternate partial } \\
\text { root-zone irrigation) }\end{array}$ & $0.110 \mathrm{a}$ & $0.242 \mathrm{a}$ & 0.238 a & $2.526 \mathrm{a}$ & $1.430 \mathrm{a}$ & $0.579 \mathrm{a}$ & $13.429 \mathrm{a}$ & $39.796 \mathrm{~b}$ & $57.183 \mathrm{a}$ & $1.564 \mathrm{a}$ & 3.419 a & $4.518 \mathrm{a}$ & $116.23 \mathrm{~b}$ & $104.79 \mathrm{~b}$ & $97.81 \mathrm{~b}$ \\
\hline $\begin{array}{l}\quad p \text {-value } \\
\text { Irrigation Techniques }\end{array}$ & 0.003 & 0.914 & 0.002 & 0.470 & 0.343 & 0.001 & 0.95 & 0.016 & 0.001 & 0.010 & 0.002 & 0.556 & 0.000 & 0.000 & 0.000 \\
\hline FUI (Furrow irrigation) & $0.105 \mathrm{~b}$ & $0.265 \mathrm{a}$ & $0.211 \mathrm{~b}$ & $2.524 \mathrm{a}$ & $1.402 \mathrm{a}$ & $0.550 \mathrm{a}$ & 16.6 & 41.386 & 52.9 & $1.482 \mathrm{a}$ & $3.263 \mathrm{a}$ & $4.583 \mathrm{a}$ & $110.66 \mathrm{~b}$ & $101.98 \mathrm{~b}$ & $94.68 \mathrm{~b}$ \\
\hline SDI (subsurface drip irrigation) & $0.109 \mathrm{a}$ & $0.219 \mathrm{~b}$ & $0.243 \mathrm{a}$ & $2.498 \mathrm{a}$ & $1.416 \mathrm{a}$ & $0.569 \mathrm{a}$ & $11.399 \mathrm{~b}$ & $40.614 \mathrm{a}$ & $55.233 \mathrm{a}$ & $1.548 \mathrm{a}$ & $3.344 \mathrm{a}$ & $4.410 \mathrm{~b}$ & $127.86 \mathrm{a}$ & $114.60 \mathrm{a}$ & $107.26 \mathrm{a}$ \\
\hline$p$-value & 0.028 & 0.004 & 0.000 & 0.522 & 0.758 & 0.089 & 0.000 & 0.400 & 0.154 & 0.070 & 0.208 & 0.026 & 0.000 & 0.000 & 0.000 \\
\hline \multicolumn{16}{|c|}{ Water Type $\times$ Irrigation Methods $\times$ Irrigation Techniques } \\
\hline$p$-value & 0.280 & 0.148 & 0.753 & 0.007 & 0.573 & 0.104 & 0.000 & 0.110 & 0.999 & 0.717 & 0.000 & 0.233 & 0.000 & 0.000 & 0.166 \\
\hline
\end{tabular}

Mean values followed by the same letter within each factor are not significantly different $(p<0.05)$ according to the Tukey test. 


\subsection{Vitamin $C$}

Vitamin C (VC) is an important antioxidant that represents the nutritional value of the fruit [72]. VC content in 2017 (first year) ranged from $0.114 \mathrm{mg} \mathrm{g}^{-1}$ to $0.086 \mathrm{mg} \mathrm{g}^{-1}$ under RW, while it was from $0.118 \mathrm{mg} \mathrm{g}^{-1}$ to $0.104 \mathrm{mg} \mathrm{g}^{-1}$ under CW. In 2018 (second year), the VC content ranged from $0.16 \mathrm{mg} \mathrm{g}^{-1}$ to $0.26 \mathrm{mg} \mathrm{g}^{-1}$ under RW, while it was from $0.24 \mathrm{mg} \mathrm{g}^{-1}$ to $0.30 \mathrm{mg} \mathrm{g}^{-1}$ under CW. In 2019 (third year), the VC content ranged from $0.19 \mathrm{mg} \mathrm{g}^{-1}$ to $0.25 \mathrm{mg} \mathrm{g}^{-1}$ under RW and from $0.21 \mathrm{mg} \mathrm{g}^{-1}$ to $0.26 \mathrm{mg} \mathrm{g}^{-1}$ under $\mathrm{CW}$, as shown in Figure 3.

In the first year, the results revead that water-saving treatment APRI under FUI with $\mathrm{CW}$ and under SDI with RW increased the VC content of tomato compared with the other treatments (Figure 3). The mean value of FUI-APRI under CW was increased by $3.69 \%$ compared with FUI-FI under the same type of water. The values of VC under SDI-APRI with RW were more than FUI-FI, FUI-APRI, and SDI-FI values, by 32.87, 10.04, and 3.19\%, respectively. The highest value of VC in the second year was with SDI-FI under CW, whereas it was with FUI-APRI under RW, while in the third year, the highest value was with SDI-APRI, both under RW and CW. In the third year, the contents of VC in SDI-APRI under RW and CW were increased by $33.85 \%$ and $22.25 \%$ respectively, as compared to FUI-FI under RW and CW.

The results demonstrate that under $\mathrm{CW}$, the highest values for all quality parameters under FUI were with APRI compared with FI in most of the readings. From the above, we note that the highest values of the VC were mostly under the APRI, whether under CW or RW. The results further illustrate that the VC of the tomato fruit was increased under the water-saving treatments. This implies that water stress can affect tomato fruit VC content positively, as observed by findings of [49,57-74]. They proved that the VC of tomato fruit was higher under the conditions of limited soil water.

The higher VC concentration in the APRI treatment could be attributed to the decreased in fruit water content [74]. The results were consistent with $[72,75]$ who reported that APRI improved the percentage of tomato fruit VC when compared to conventional drip irrigation. Deficit irrigation methods like APRI can enhance tomato fruit quality in terms of VC and acidity, when compared to full irrigation [43,44].

The analysis of variances in the three years of the experimental period showed a significant effect $(p<0.05)$ of irrigation water qualities, irrigation methods, and irrigation techniques on $\mathrm{VC}$, except the irrigation methods in the second year and irrigation water qualities in the third year. However, there was no significant effect $(p>0.05)$ of the interaction between the experimental factors on VC through the three years.

Table 2 shows that the means under RW were less than that under $\mathrm{CW}$ in all three years, except in the third year. These results agree to some extent with [76], who found a negative impact on organic acid, protein, and vitamin $\mathrm{C}$ content in tomato crops subjected to RW irrigation.

However, $[77,78]$ found that using RW had no significant impact on tomato fruit quality. These contradictory results depend on several factors such as the concentration of nutrients in the RW as well as the length of time this sort of water was utilized for irrigation [30], different species, different climatic conditions, cultivars, cultural practices, stages of maturity, and growing conditions. According to the irrigation methods, the mean under APRI was significantly $(p<0.05)$ higher in the first and third years than under FI. The mean for SDI in the first and third years was significantly $(p<0.05)$ higher than FUR.

According to the irrigation methods, the mean under APRI was significantly $(p<0.05)$ higher than that under FI, with a significant effect in the first and third years. The mean for all readings under SDI in the first and third years was higher than FUR, with a significant effect in the three years. 

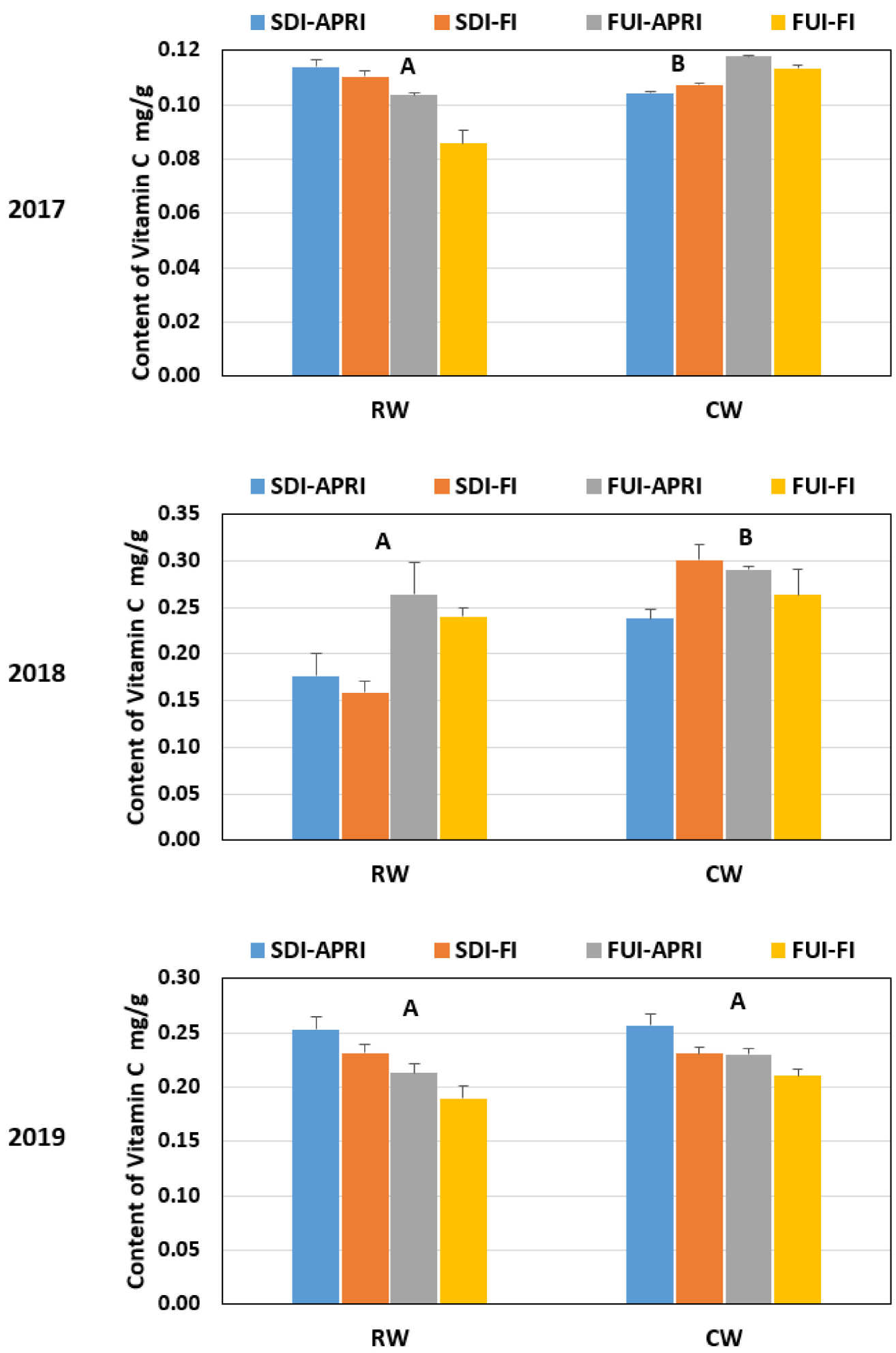

Figure 3. Content of Vitamin C (mg/g) for the different irrigation treatments in tomatoes for the three years. The different capital letters on the top of the figure represented significant differences between water types at $p<0.05$. Bars give the means \pm standard error of the mean $(n=3)$. RW: reclaimed water, CW: clean water, SDI: subsurface drip irrigation, APRI: alternate partial root-zone irrigation, FI: full irrigation, FUI: furrow irrigation.

\subsection{Total Acidity}

In most readings, the total acidity (TA) of tomato fruit was enhanced during APRI treatments. The values of TA content in the 1st year ranged from $2.45-2.69 \%$ under RW, 
while it was 2.36-2.61\% under CW. In the second year, the TA content ranged from 1.40 to $1.45 \%$ under RW, while it was $1.30-1.43 \%$ under CW. In the third year, it ranged from 0.52 to $0.61 \%$ under RW, and from 0.53 to $0.62 \%$ under CW (Figure 4 ).

2017

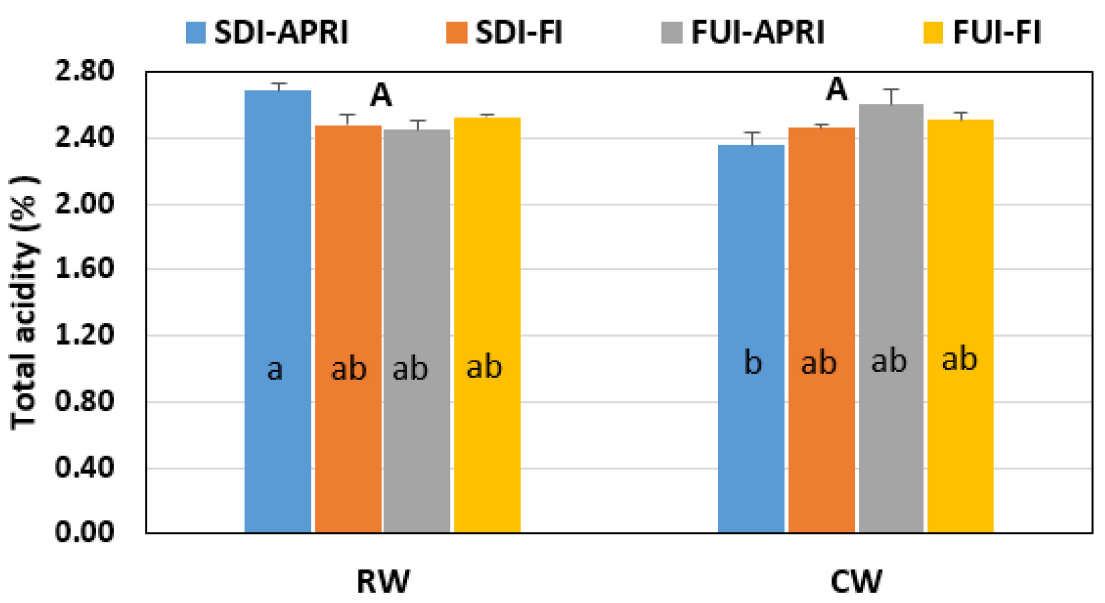

2018
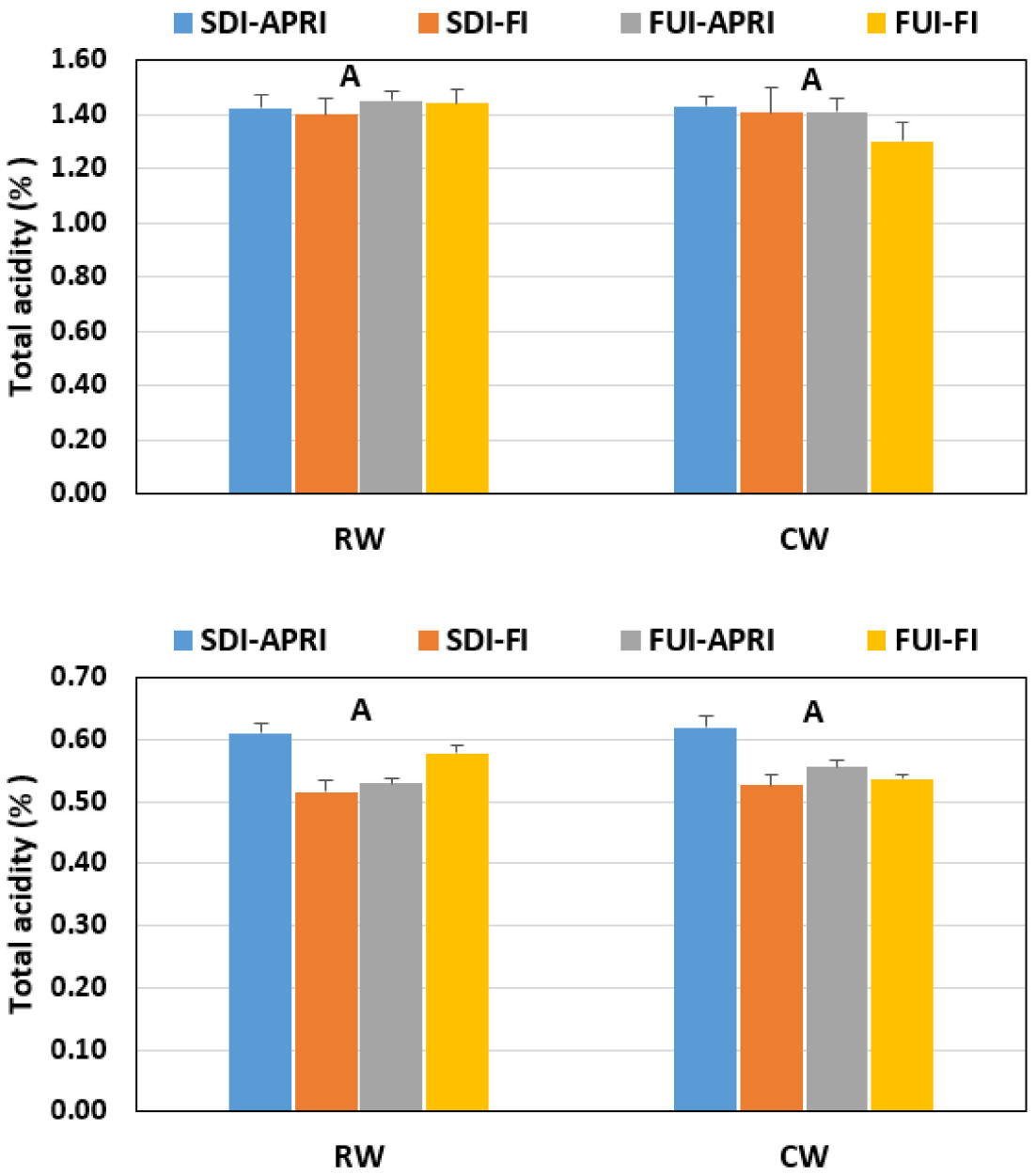

Figure 4. Total acidity (\%) for the different irrigation treatments in tomato for the three years. The different capital letters on the top of the figure represented significant differences between water types at $p<0.05$. Different letters within columns revealed significant differences between irrigation treatments at $p<0.05$. Bars give the means \pm standard error of the mean $(n=3)$. RW: reclaimed water, $\mathrm{CW}$ : clean water, SDI: subsurface drip irrigation, APRI: alternate partial root-zone irrigation, FI: full irrigation, FUI: furrow irrigation. 
The TA maximum value in the first year was with SDI-APRI under RW, which was $8.38 \%, 9.79 \%$, and $6.46 \%$ higher than SDI-FI, FUI-APRI, and FUI-FI, respectively. Similarly, the maximum value of TA under CW was with FUI-APRI, which was increased by $3.71 \%$, $10.60 \%$, and $5.81 \%$ as compared with FUI-FI, SDI-APRI and SDI-FI, respectively.

In the second year, the results revealed that the TA value of FUI-APRI under RW was the highest amongst all the treatments. It increased slightly by $2.11 \%, 3.71 \%$, and $0.81 \%$ compared with SDI-APRI, SDI-FI, and FUI-FI under RW, respectively. The highest value of TA under CW was with SDI-APRI and increased by $9.78 \%$ more than FUI-FI and by $1.30 \%$ more than the other treatments.

In the third year, the TA values under SDI-APRI, both under CW and RW, were the highest compared with the other treatment. The value of TA under SDI-APRI with RW increased more than the SDI-FI, FUI- APRI, and FUI-FI under RW by $18.51 \%, 15.46 \%$, and $5.76 \%$, respectively. The TA value under SDI-APRI with CW was increased by $17.64 \%$ more than SDI-FI, and by 11.50 and $15.33 \%$ more than FUI-APRI and FUI-FI under $\mathrm{CW}$, respectively.

It was noticed that the TA's highest values mostly were under RW, and that is in agreement with [79], who emphasized that the TA of tomato increased under the treatment of RW. That may be because the RW can supply sufficient nutrients for plants [65]. According to references [80-82], RW irrigation is helpful because of the large amount of nutrients required to maintain soil fertility and raise plant quality, productivity, and growth.

According to statistical analysis, there were no significant differences observed $(p>0.05)$ among the levels of each factor on tomato TA in the three years, except the irrigation methods in the third year, where there was a significant difference $(p<0.05)$ between FUR and SDI on tomato TA. The statistical analysis demonstrated no significant effect $(p>0.05)$ in the interaction between the experimental factors on TA through the second and third years. Still, there was a significant effect $(p<0.05)$ in the first year. Figure 4 in the first year shows the significant differences between the treatments means.

Our finding is consistent with that of [83], who concluded that water sources and the irrigation practices had no significant $(p>0.05)$ effect on tomato TA. Moreover, this result is consistent with [84], who expressed that compared with tap water, the tomato VC and fruit acidity content under reclaimed municipal wastewater had no significant difference. Many previous studies demonstrated non-significant changes in the quality of tomato fruit when the tomato was irrigated with RW $[20,77,78,83,85]$.

Our study results show that most readings of TA value were increased under APRI treatments, which is consistent with $[43,55,57]$, who pointed out that the tomato acidity values under deficit irrigation treatments were improved compared to FI.

Refs. $[43,55,57]$ reported that the smaller fruit size and low dilution caused by lower water levels within the fruits resulted in accumulation of the assimilates, thereby improving the quality parameters.

Our results agree with the finding of [75], who stated that increasing fructose, glucose, sucrose, citric acid, and malic in tomatoes under water stress improved fruit quality. Ref. [73] manifested that TA curvilinearly increased as the soil water deficit increased. Ref. [86] also found that the restriction of water supply throughout the development or maturation stages of fruit growth resulted in a considerable rise in fruit acidity.

A similar trend for values of TA in response to water deficit was reported by [87] for processing tomatoes under various water regimes. Ref. [49] also found that the treatments of deficit irrigation improved TA compared to full irrigation treatment.

The present study agreed with [20], who emphasized that the acidity of tomatoes was not significantly affected by the different water types. Ref. [88] reported that RW significantly increased TA and VC, whereas fewer irrigation quantities provided significantly lower TA, VC. That findings agree with our results because the interaction between the RW and APRI resulted in no significant effect on the TA and VC of tomato (Table 2). 


\subsection{Protein Content}

Protein Content (PC) in tomato fruit is an important quality parameter. PC value in the first year ranged from $6.39 \mathrm{mg} 100 \mathrm{~g}^{-1}$ to $20.45 \mathrm{mg} 100 \mathrm{~g}^{-1}$, while it ranged from

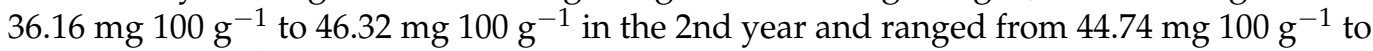

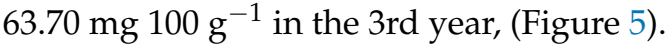

2017
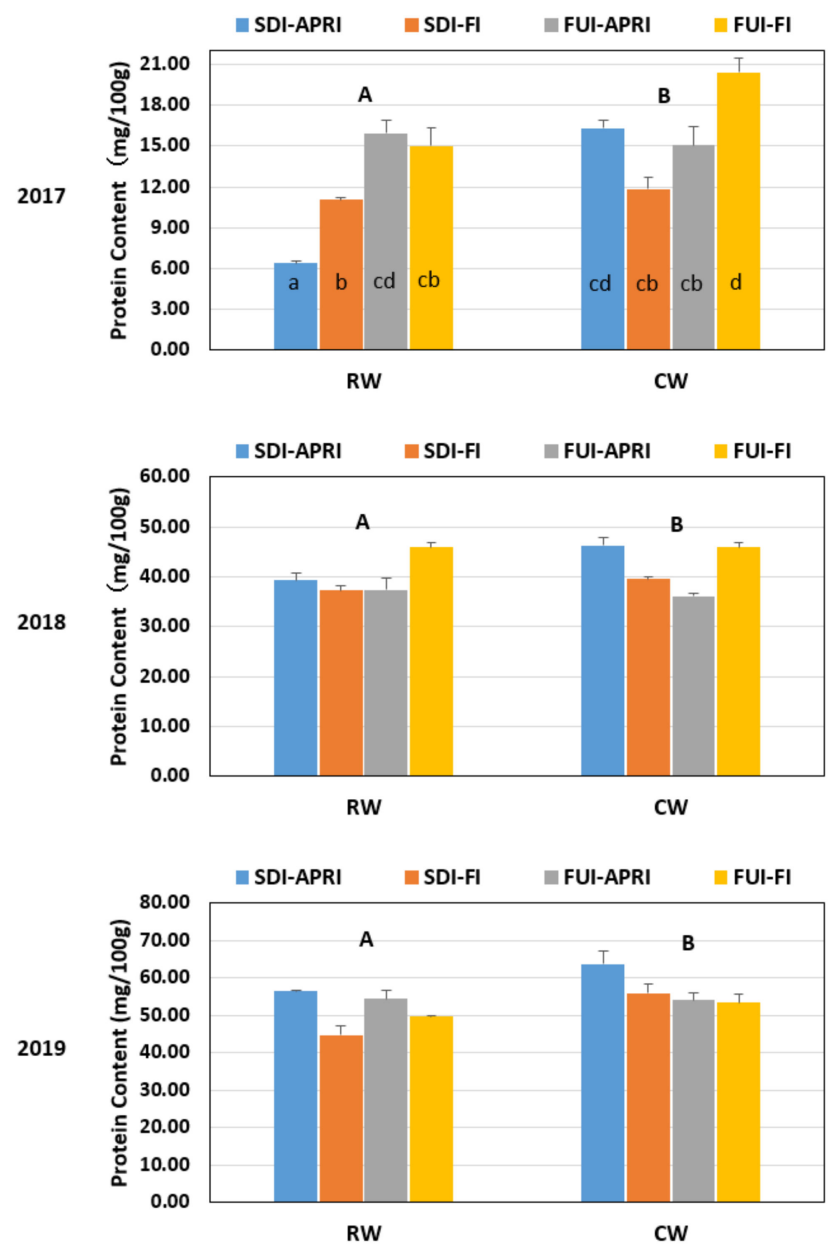

Figure 5. Protein Content $(\mathrm{mg} / 100 \mathrm{~g})$ for the different irrigation treatments in tomatoes for the three years. The different capital letters on the top of the figure represented significant differences between water types at $p<0.05$. Different letters within columns revealed significant differences between irrigation treatments at $p<0.05$. Bars give the means \pm standard error of the mean $(n=3)$. RW: reclaimed water, $C W$ : clean water, SDI: subsurface drip irrigation, APRI: alternate partial rootzone irrigation, FI: full irrigation, FUI: furrow irrigation.

Our study showed that in the first year, the highest value of PC under RW was with FUI-APRI while it was with FUI-FI under CW. Among the eight treatments in the second year, SDI-APRI under CW had the highest PC, followed by FUI-FI under RW, with the values of 46.32 and $45.96 \%$, respectively. In the third year, the SDI-APRI treatment had the highest PC value, whether under CW or RW, with 63.70 and $56.54 \%$, respectively.

We noticed that during the first two years, the PC content was sometimes higher under APRI and sometimes higher under FI, while in the third year, the PC content under APRI was higher than that under FI. The higher PC concentration in the APRI treatments could be attributed to reduction in the water content of the fruit under APRI treatments. Ref. [89] reported that the APRI method improved secondary root growth, thereby enhancing the plants' ability to absorb the nutrients from the soil and thus enhancing nutrient use efficiency. Ref. [90] also stated that APRI could enhance nutrient-use efficiency. Ref. [91] 
studied the effect of APRI and secondary-treated wastewater on soil nitrogen, and they found that APRI enhanced nitrogen use efficiency.

Figure 5 shows that under the $\mathrm{CW}$, the most measured values of PC were slightly higher than the corresponding values under the RW. However, in much research, the authors illustrated that the RW irrigation increased the PC of some plants such as sorghum, grass, forage, corn, wheat, and millet [92-94]. This result was expected because RW is high in nutrients, particularly nitrogen, which is essential for plant protein synthesis. [95].

Statistical analyses during the three years illustrated a significant effect $(p<0.05) \mathrm{pf}$ water qualities on the PC. Table 2 shows that the mean value was higher under the CW than under RW in the three years. In addition, there were significant differences observed in tomato PC between the irrigation methods in the second and third years. The highest mean in the second year was with FI, while it was with APRI in the third year (Table 2). The irrigation techniques had no significant effects $(p>0.05)$ on tomato PC except in the 1 st year. Moreover, there was no significant effect $(p<0.05)$ on the interaction between the experimental factors on PC through the second and third years. Figure 5 at the first year shows which of treatments means have a significant difference.

\subsection{Total Soluble Sugar Content}

Our study found that the total soluble sugar content value (TSS) in the first year ranged from 1.28 to $1.67 \%$, and ranged from 3.01 to $3.79 \%$ in the second year, while it ranged from 3.93 to $5.08 \%$ in the third year, as shown in Figure 6.
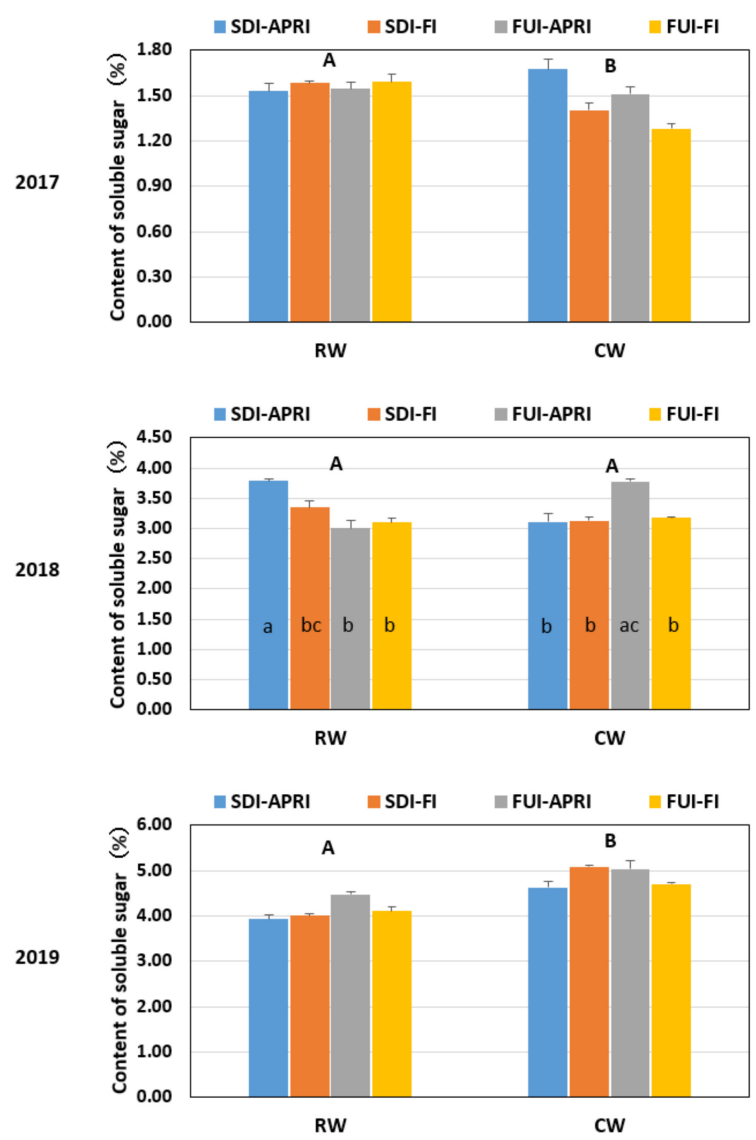

Figure 6. Content of soluble sugar (\%) for the different irrigation treatments in tomato for the three years. The different capital letters on the top of the figure represented significant differences between water types at $p<0.05$. Different letters within columns revealed significant differences between irrigation treatments at $p<0.05$. Bars give the means \pm standard error of the mean $(n=3)$. RW: reclaimed water, CW: clean water, SDI: subsurface drip irrigation, APRI: alternate partial rootzone irrigation, FI: full irrigation, FUI: furrow irrigation. 
In the first year, the results illustrate that SDI-APRI under CW had the highest TSS value $(1.67 \%)$, followed by FUI-FI under RW $(1.59 \%)$. The results in the second year show increasing the TSS for SDI-APRI under RW compared with all treatments. It was increased by 22.42 and $19.38 \%$, respectively, over the value of FUI-FI under RW and CW, whereas in the third year, the highest value under RW was with the FUI-APRI (4.47\%), and the highest value under CW was with the SDI-FI (5.08\%).

Therefore, the highest TSS value through the three years was with the APRI, both under RW and CW, which is in agreement with what [74] reported. They reported that the TSS concentrations under water-saving treatments were higher than the TSS value under full irrigation treatment, and they attributed that to a lower fruit water content, whereas the net dry matter accumulation was less affected.

The analysis of variances showed a significant effect $(p<0.05)$ of water qualities on TSS through the first and third years. Table 2 shows that in the first year, the mean of all measurements under RW was higher than under CW, while the opposite was in the third year.

RW irrigation enhances taste indexes of tomatoes, such as titratable acidity and soluble sugar of fruit to a certain extent [31]. However, [84] illustrated that the TSS under reclaimed municipal wastewater was no significantly different compared with tap water. Moreover, [32] found that using RW had a negligible effect on the TSS in tomato fruit after irrigation with RW. Ref. [30] demonstrated that the researchers pointed out that there is no significant effect on vegetable quality (vitamin C, soluble sugar, coarse ash, amino acid content, and nitrate levels) when using RW irrigation.

Analysis of variances showed a significant effect of irrigation methods on TSS through the first and second years. The highest mean was in the APRI compared with FI as shown in Table 2. Ref. [96] found a negative linear relationship between irrigation water quantity and TSS. The soil water manipulation by applying APRI throughout the growing season or from flowering onwards increased the TSS content of the fruits [53].

Ref. [97] illustrated that the TSS will rise in the fruit under water deficit because of a higher conversion of starch to sugars. The high content of TSS in tomatoes is favorable for the tomato processing industry because it improves the processing efficiency [98].

There was no significant effect $(p>0.05)$ due to irrigation techniques on TSS in the first and second years. Moreover, no significant effect $(p<0.05)$ to the interaction between the experimental factors on TSS through the first and third years. There was a significant interaction between the factors on TSS in the second year. Figure 6 at the second year shows the significant difference between the treatment means.

Overall, the summary of the analysis of variances on tomato quality parameter across the experimental factors in the three years shows that there was mostly a significant effect $(p<0.05)$ due to water qualities as well as irrigation methods on the studied parameter of tomato quality, except TA. Moreover, notice that there is no observable trend for the irrigation techniques effect. As a general trend, there was no significant effect $(p>0.05)$ of the interaction between the experimental factors on tomato fruit quality.

In short, the results can be summarized as follows: In many readings, the tomato fruit quality was increased under APRI treatments. Moreover, many measurements under RW had higher values compared with CW; many measurements under CW had higher values compared with RW. The most measured values of the PC under CW were slightly greater than the values under RW. In addition, the treatment of SDI-APRI resulted in increased values of tomato quality parameters in many readings, whether under RW or CW.

\section{Conclusions}

Using reclaimed wastewater to irrigate crops is a sustainable practice that helps to decrease freshwater wastage and conserve water supply. In this research, we studied the effects of two types of water qualities (reclaimed wastewater (RW) and clean water (CW)), two types of irrigation methods (Full irrigation (FI) and alternate partial root-zone irrigation $(\mathrm{APRI})$ ), and two types of irrigation techniques (Furrow irrigation (FUI) and subsurface 
drip irrigation (SDI)) on the main tomato fruit quality parameters. The experimental results from all the three years show that treatment of SDI-APRI under RW can be an effective irrigation method to reduce the consumption of clean water since there is no significant effect of the interaction between the experimental factors on tomato fruit quality. Thus, we recommend using the treatment of SDI-APRI under RW with effective management. We also recommend conducting future studies to investigate the environmental and economic aspects of treated wastewater irrigation under different irrigation techniques.

Author Contributions: Conceptualization, M.S.H., W.G., X.Q. and P.L.; methodology, M.S.H., W.G. X.Q. and P.L.; formal analysis, M.S.H., W.G., X.Q. and P.L.; investigation, M.S.H., W.G., X.Q. and P.L.; resources, M.S.H., W.G., X.Q. and P.L.; writing-original draft preparation, M.S.H., W.G., X.Q. and P.L.; writing-review and editing, M.S.H., W.G., X.Q. and P.L.; visualization, M.S.H., W.G., X.Q. and P.L.; supervision, X.Q.; project administration, X.Q.; funding acquisition, X.Q. All authors have read and agreed to the published version of the manuscript.

Funding: This research was funded by National Natural Science Foundation of China, grant number 51679241, 51709265 and Agricultural Science and Technology Innovation Program, grant number CAAS-ASTIPFIRI-03.

Institutional Review Board Statement: Not applicable.

Informed Consent Statement: Not applicable.

Data Availability Statement: Not applicable.

Conflicts of Interest: The authors declare no conflict of interest. The funders had no role in the design of the study; in the collection, analyses, or interpretation of data; in the writing of the manuscript, or in the decision to publish the results.

\section{References}

1. Wolf, A.T. Water and human security. J. Contemp. Water Res. Educ. 2001, 118, 5.

2. Xiao, Y.; Shao, J.; Cui, Y.; Zhang, G.; Zhang, Q. Groundwater circulation and hydrogeochemical evolution in Nomhon of Qaidam Basin, northwest China. J. Earth Syst. Sci. 2017, 126, 26. [CrossRef]

3. Hussain, M.I.; Muscolo, A.; Farooq, M.; Ahmad, W. Sustainable use and management of non-conventional water resources for rehabilitation of marginal lands in arid and semiarid environments. Agric. Water Manag. 2019, 221, 462-476. [CrossRef]

4. Guterres, A. The Sustainable Development Goals Report United Nations; United Nations: New York, NY, USA, 2017.

5. World Bank. Water Resources Management. Available online: https//www.worldbank.org/en/topic/ (accessed on 11 October 2021).

6. Becerra-Castro, C.; Lopes, A.R.; Vaz-Moreira, I.; Silva, E.F.; Manaia, C.M.; Nunes, O.C. Wastewater reuse in irrigation: A microbiological perspective on implications in soil fertility and human and environmental health. Environ. Int. 2015, 75, 117-135. [CrossRef]

7. Chojnacka, K.; Witek-Krowiak, A.; Moustakas, K.; Skrzypczak, D.; Mikula, K.; Loizidou, M. A transition from conventional irrigation to fertigation with reclaimed wastewater: Prospects and challenges. Renew. Sustain. Energy Rev. 2020, 130, 109959. [CrossRef]

8. Rizzo, L.; Gernjak, W.; Krzeminski, P.; Malato, S.; McArdell, C.S.; Perez, J.A.S.; Schaar, H.; Fatta-Kassinos, D. Best available technologies and treatment trains to address current challenges in urban wastewater reuse for irrigation of crops in EU countries. Sci. Total Environ. 2020, 710, 13631. [CrossRef]

9. Hussain, M.I.; Qureshi, A.S. Health risks of heavy metal exposure and microbial contamination through consumption of vegetables irrigated with treated wastewater at Dubai, UAE. Environ. Sci. Pollut. Res. 2020, 27, 11213-11226. [CrossRef]

10. Feng, H.; Tan, D.; Lazareva, I. 8 Facts on China's Wastewater. Available online: http// chinawaterrisk.org/Resour (accessed on 30 April 2018).

11. NPSCB. 1st National Pollutant Source Census Bulletin; China Press: Kuala Lumpur, Malaysia, 2010.

12. Ghernaout, D. The Best Available Technology of Water/Wastewater Treatment and Seawater Desalination: Simulation of the Open Sky Seawater Distillation. Green Sustain. Chem. 2013, 03, 68-88. [CrossRef]

13. Ghernaout, D. Increasing Trends Towards Drinking Water Reclamation from Treated Wastewater. World J. Appl. Chem. 2018, 3, 1. [CrossRef]

14. Kiziloglu, F.; Turan, M.; Sahin, U.; Kuslu, Y.; Dursun, A. Effects of untreated and treated wastewater irrigation on some chemical properties of cauliflower (Brassica olerecea L. var. botrytis) and red cabbage (Brassica olerecea L. var. rubra) grown on calcareous soil in Turkey. Agric. Water Manag. 2008, 95, 716-724. [CrossRef]

15. Xu, J.; Wu, L.; Chang, A.C.; Zhang, Y. Impact of long-term reclaimed wastewater irrigation on agricultural soils: A pre-liminary assessment. J. Hazard. Mater. 2010, 183, 780-786. [CrossRef] [PubMed] 
16. Li, Y.-F.; Li, J.-S.; Zhang, H. Effects of Chlorination on Soil Chemical Properties and Nitrogen Uptake for Tomato Drip Irrigated with Secondary Sewage Effluent. J. Integr. Agric. 2014, 13, 2049-2060. [CrossRef]

17. Wu, W.; Xu, C.; Liu, H.; Hao, Z.; Ma, F.; Ma, Z. Effect of reclaimed water irrigation on yield and quality of fruity vegetables. Trans. Chin. Soc. Agric. Eng. 2010, 26, 36-40.

18. Xue, Y.-D.; Yang, P.-L.; Ren, S.-M.; Liu, H.; Wu, W.-Y.; Su, Y.-P.; Fang, Y.-X. [Effects of irrigation with treated wastewater on nutrient distribution in cucumber and tomato plants and their fruit quality]. Ying Yong Sheng Tai Xue Bao/J. Appl. Ecol. 2011, 22, 395-401.

19. Chen, W.; Lu, S.; Peng, C.; Jiao, W.; Wang, M. Accumulation of Cd in agricultural soil under long-term reclaimed water irrigation. Environ. Pollut. 2013, 178, 294-299. [CrossRef] [PubMed]

20. Gatta, G.; Libutti, A.; Gagliardi, A.; Disciglio, G.; Beneduce, L.; D'Antuono, M.; Rendina, M.; Tarantino, E. Effects of treated agro-industrial wastewater irrigation on tomato processing quality. Ital. J. Agron. 2015, 10, 97-100. [CrossRef]

21. Gianfreda, L.; Rao, M.A.; Piotrowska-Długosz, A.; Palumbo, G.; Colombo, C. Soil enzyme activities as affected by anthropogenic alterations: Intensive agricultural practices and organic pollution. Sci. Total Environ. 2005, 341, 265-279. [CrossRef]

22. Aboutalebi, A.; Khankahdani, H.H.; Zakeri, E. Study on yield and quality of 16 tomato cultivars in south of Iran. Int. Res. J. Appl. Basic Sci. 2012, 3, 838-841.

23. Teka, T.A. Analysis of the effect of maturity stage on the postharvest biochemical quality characteristics of tomato (Lycopersicon esculentum Mill.) fruit. Int. Res. J. Pharm. Appl. Sci. 2013, 3, 180-186.

24. Tigist, M.; Workneh, T.S.; Woldetsadik, K. Effects of variety on the quality of tomato stored under ambient conditions. J. Food Sci. Technol. 2013, 50, 477-486. [CrossRef]

25. Munhuewyi, K. Postharvest Losses and Changes in Quality of Vegetables from Retail to Consumer: A Case Study of Tomato, Cabbage and Carrot. Master's Thesis, Stellenbosch University, Stellenbosch, South Africa, 2012.

26. Saad, A.G.; Jaiswal, P.; Jha, S.N. Non-destructive quality evaluation of intact tomato using VIS-NIR spectroscopy. Int. J. Adv. Res. 2014, 2, 632-639.

27. Kafkas, E.; Koşar, M.; Paydaş, S.; Kafkas, S.; Başer, K. Quality characteristics of strawberry genotypes at different maturation stages. Food Chem. 2007, 100, 1229-1236. [CrossRef]

28. Sadasivam, S. Biochemical Methods; New Age International: New Delhi, India, 1996.

29. Wilkerson, E.D.; Anthon, G.E.; Barrett, D.M.; Sayajon, G.F.G.; Santos, A.M.; Rodriguez-Saona, L.E. Rapid Assessment of Quality Parameters in Processing Tomatoes Using Hand-Held and Benchtop Infrared Spectrometers and Multivariate Analysis. J. Agric. Food Chem. 2013, 61, 2088-2095. [CrossRef] [PubMed]

30. Wang, Z.; Li, J.; Li, Y. Using Reclaimed Water for Agricultural and Landscape Irrigation in China: A Review. Irrig. Drain. 2017, 66, 672-686. [CrossRef]

31. Lu, S.; Zhang, X.; Liang, P. Influence of drip irrigation by reclaimed water on the dynamic change of the nitrogen element in soil and tomato yield and quality. J. Clean. Prod. 2016, 139, 561-566. [CrossRef]

32. Al-Lahham, O.; El Assi, N.; Fayyad, M. Impact of treated wastewater irrigation on quality attributes and contamination of tomato fruit. Agric. Water Manag. 2003, 61, 51-62. [CrossRef]

33. L-Momany, A.A.; Arabiat, S.; Fardous, A. Growth and quality of tomato irrigated with treated waste water to control Fusarium wilt. Int. J. Water Res. Environ. Eng. 2014, 3, 161-176.

34. Martijn, E.-J.; Kampf, R.; Claassen, T.; Mels, A. Use of the Waterharmonica for conversion of treated waste water into a natural resource in the developing world. In Proceedings of the Ecological Engineering for Integrated Water Management, Cambridge, MA, USA, 30 October-2 November 2003.

35. Adamala, S.; Raghuwanshi, N.; Mishra, A. Development of Surface Irrigation Systems Design and Evaluation Software (SIDES). Comput. Electron. Agric. 2014, 100, 100-109. [CrossRef]

36. Qi, Z.; Zhang, T.; Zhou, L.; Feng, H.; Zhao, Y.; Si, B. Combined Effects of Mulch and Tillage on Soil Hydrothermal Conditions under Drip Irrigation in Hetao Irrigation District, China. Water 2016, 8, 504. [CrossRef]

37. Gatta, G.; Libutti, A.; Gagliardi, A.; Disciglio, G.; Tarantino, E.; Beneduce, L.; Giuliani, M.M. Wastewater Reuse in Agriculture: Effects on Soil-Plant System Properties. In Interaction and Fate of Pharmaceuticals in Soil-Crop Systems; The Handbook of Environmental Chemistry; Pérez Solsona, S., Montemurro, N., Chiron, S., Barceló, D., Eds.; Springer: Cham, Switzerland, 2020; Volume 24, pp. 79-102.

38. Mahmoudi, M.; Khelil, M.N.; Ghrib, R.; Douh, B.; Boujelben, A. Assessment of growth and yield of okra (Abelmoschus esculentus) under surface and subsurface drip irrigation using treated waste water. Int. J. Recycl. Org. waste Agric. 2020, 9, 349-356.

39. Kahlon, M.S.; Josan, A.S.; Khera, K.L.; Choudhary, O.P. Effect of drip and furrow methods of irrigation on tomato under two irrigation levels. Indian J. Agric. Res. 2007, 41, 282-286.

40. Hashem, M.; Qi, X. Treated Wastewater Irrigation-A Review. Water 2021, 13, 1527. [CrossRef]

41. Ahmadi, S.H.; Andersen, M.N.; Plauborg, F.; Poulsen, R.T.; Jensen, C.R.; Sepaskhah, A.R.; Hansen, S. Effects of irrigation strategies and soils on field-grown potatoes: Gas exchange and xylem [ABA]. Agric. Water Manag. 2010, 97, 1486-1494. [CrossRef]

42. Yu, Y.; Wen, B.; Yang, Y.; Lu, Z.H. The Effects of Treated Wastewater Irrigation on Soil Health. Adv. Mater. Res. 2011, 393-395, 1545-1549. [CrossRef]

43. Nangare, D.D.; Singh, Y.; Kumar, P.S.; Minhas, P.S. Growth, fruit yield and quality of tomato (Lycopersicon esculentum Mill.) as affected by deficit irrigation regulated on phenological basis. Agric. Water Manag. 2016, 171, 73-79. [CrossRef] 
44. Akhtar, S.S.; Li, G.; Andersen, M.N.; Liu, F. Biochar enhances yield and quality of tomato under reduced irrigation. Agric. Water Manag. 2014, 138, 37-44. [CrossRef]

45. GB5084-2005; Standards for Irrigation Water Quality. Ministry of Agriculture of the People Republic of China: Beijing, China, 2006. (In Chinese)

46. Liu, F.; Shahnazari, A.; Andersen, M.N.; Jacobsen, S.-E.; Jensen, C.R. Physiological responses of potato (Solanum tuberosum L.) to partial root-zone drying: ABA signalling, leaf gas exchange, and water use efficiency. J. Exp. Bot. 2006, 57, 3727-3735. [CrossRef]

47. Allen, R.; Pereira, L.; Raesk, D.; Smith, M. Crop Evapotranspiration-Guidelines for Computing Crop Water Requirements; Food and Agriculture Organization (FAO): Rome, Italy, 1998.

48. Von Zabeltitz, C. Integrated Greenhouse Systems for Mild Climates: Climate Conditions, Design, Construction, Maintenance, Climate Control; Springer Science \& Business Media: Berlin/Heidelberg, Germany, 2010.

49. Patanè, C.; Tringali, S.; Sortino, O. Effects of deficit irrigation on biomass, yield, water productivity and fruit quality of processing tomato under semi-arid Mediterranean climate conditions. Sci. Hortic. 2011, 129, 590-596. [CrossRef]

50. Turhan, A.; Şeniz, V. Estimation of certain chemical constituents of fruits of selected tomato genotypes grown in Turkey. Afr. J. Agric. Res. 2009, 4, 1086-1092.

51. Association of Official Agricultural Chemists (AOAC). Official Methods of Analysis, 16th ed.; AOAC: Gaithersburg, MD, USA, 1999.

52. Wei, Y.-J.; Li, K.-A.; Tong, S.-Y. A linear regression method for the study of the Coomassie brilliant blue protein assay. Talanta 1997, 44, 923-930. [CrossRef]

53. Giuliani, M.M.; Gatta, G.; Nardella, E.; Tarantino, E. Water saving strategies assessment on processing tomato cultivated in Mediterranean region. Ital. J. Agron. 2015, 10, 69. [CrossRef]

54. Hashem, M.S.; El-Abedin, T.Z.; Al-Ghobari, H.M. Rational water use by applying regulated deficit and partial root-zone drying irrigation techniques in tomato under arid conditions. Chil. J. Agric. Res. 2019, 79, 75-88. [CrossRef]

55. Kuscu, H.; Turhan, A.; Ozmen, N.; Aydinol, P.; Demir, A.O. Optimizing levels of water and nitrogen applied through drip irrigation for yield, quality, and water productivity of processing tomato (Lycopersicon esculentum Mill.). Hortic. Environ. Biotechnol. 2014, 55, 103-114. [CrossRef]

56. Savić, S.; Stikić, R.; Radović, B.V.; Bogičević, B.; Jovanović, Z.; Šukalović, V.H.-T. Comparative effects of regulated deficit irrigation (RDI) and partial root-zone drying (PRD) on growth and cell wall peroxidase activity in tomato fruits. Sci. Hortic. 2008, 117, 15-20. [CrossRef]

57. Zheng, J.; Huang, G.; Jia, D.; Wang, J.; Mota, M.; Pereira, L.S.; Huang, Q.; Xu, X.; Liu, H. Responses of drip irrigated tomato (Solanum lycopersicum L.) yield, quality and water productivity to various soil matric potential thresholds in an arid region of Northwest China. Agric. Water Manag. 2013, 129, 181-193. [CrossRef]

58. Jensen, C.R.; Battilani, A.; Plauborg, F.; Psarras, G.; Chartzoulakis, K.; Janowiak, F.; Stikic, R.; Jovanovic, Z.; Li, G.; Qi, X.; et al. Deficit irrigation based on drought tolerance and root signalling in potatoes and tomatoes. Agric. Water Manag. 2010, 98, 403-413. [CrossRef]

59. Mukherjee, A.; Kundu, M.; Sarkar, S. Role of irrigation and mulch on yield, evapotranspiration rate and water use pattern of tomato (Lycopersicon esculentum L.). Agric. Water Manag. 2010, 98, 182-189. [CrossRef]

60. Islam, M.T. Effect of temperature on photosynthesis, yield attributes and yield of tomato genotypes. Int. J. Expt. Agric. 2011, $2,8-11$.

61. Zegbe, J.; Behboudian, M.; Clothier, B. Partial rootzone drying is a feasible option for irrigating processing tomatoes. Agric. Water Manag. 2004, 68, 195-206. [CrossRef]

62. Gu, X.; Xiao, Y.; Yin, S.; Liu, H.; Men, B.; Hao, Z.; Qian, P.; Yan, H.; Hao, Q.; Niu, Y.; et al. Impact of Long-Term Reclaimed Water Irrigation on the Distribution of Potentially Toxic Elements in Soil: An In-Situ Experiment Study in the North China Plain. Int. J. Environ. Res. Public Health 2019, 16, 649. [CrossRef]

63. Li, B.; Cao, Y.; Guan, X.; Li, Y.; Hao, Z.; Hu, W.; Chen, L. Microbial assessments of soil with a 40-year history of reclaimed wastewater irrigation. Sci. Total Environ. 2019, 651, 696-705. [CrossRef]

64. Emongor, V.; Macheng, B.; Kefilwe, S. Effects of secondary sewage effluent on the growth, development, fruit yield and quality of tomatoes (Lycopersicon lycopersicum (L.) karten). Acta Hortic. 2008, 944, 29-40. [CrossRef]

65. Guo, W.; Andersen, M.N.; Qi, X.-B.; Li, P.; Li, Z.-Y.; Fan, X.-Y.; Zhou, Y. Effects of reclaimed water irrigation and nitrogen fertilization on the chemical properties and microbial community of soil. J. Integr. Agric. 2017, 16, 679-690. [CrossRef]

66. Teklehaimanot, G.Z.; Kamika, I.; Coetzee, M.A.A.; Momba, M.N.B. Seasonal variation of nutrient loads in treated wastewater effluents and receiving water bodies in Sedibeng and Soshanguve, South Africa. Environ. Monit. Assess. 2015, 187, 595. [CrossRef] [PubMed]

67. Huang, Z.; Miao, Z.; Hou, L.; Jiao, Z.; Ma, A.M. Effect of irrigation time and mode with reclaimed water on growth and quality of crops. J. Agro-Environ. Sci. 2007, 6, 1-10.s.

68. Jamjoum, K.I.; Khattari, S.K. Effect of wastewater and sludge application on soil, corn plant composition and production in Zizia Region. Dirasat 1986, 15, 29-44.

69. Najafi, P. Effects of Using Subsurface Drip Irrigation and Treated Municipal Waste Water in Irrigation of Tomato. Pak. J. Biol. Sci. 2006, 9, 2672-2676. [CrossRef]

70. Singh, H.P.; Kaushish, S.P.; Kumar, A.; Murthy, T.S.; Samuel, J.C. Micro-irrigation. In Proceedings of the International Conference on Micro and Sprikler Irrigation Systems, Jalgaon, India, 8-10 February 2000; pp. 8-10. 
71. Khawla, K.; Besma, K.; Enrique, M.; Mohamed, H. Accumulation of trace elements by corn (Zea mays) under irrigation with treated wastewater using different irrigation methods. Ecotoxicol. Environ. Saf. 2019, 170, 530-537. [CrossRef]

72. Yang, L.; Qu, H.; Zhang, Y.; Li, F. Effects of partial root-zone irrigation on physiology, fruit yield and quality and water use efficiency of tomato under different calcium levels. Agric. Water Manag. 2012, 104, 89-94. [CrossRef]

73. Patanè, C.; Cosentino, S. Effects of soil water deficit on yield and quality of processing tomato under a Mediterranean climate. Agric. Water Manag. 2010, 97, 131-138. [CrossRef]

74. Hashem, M.S.; El-Abedin, T.Z.; Al-Ghobari, H.M. Assessing effects of deficit irrigation techniques on water productivity of tomato for subsurface drip irrigation system. Int. J. Agric. Biol. Eng. 2018, 11, 137-145. [CrossRef]

75. Nahar, K.; Ullah, S.M.; Islam, N. Osmotic adjustment and quality response of five tomato cultivars (Lycopersicon esculentum Mill.) following water deficit stress under subtropical climate. Asian J. Plant. Sci. 2011, 10, 153-157. [CrossRef]

76. Li, B.; Ren, S.; Zhang, X.; Kong, Q. Study on quality of tomato and heavy metal in soil and fruit contribution with irrigation of rejuvenated water. J. Soil Water Conserv. 2007, 21, 163-165.

77. Cirelli, G.L.; Consoli, S.; Licciardello, F.; Aiello, R.; Giuffrida, F.; Leonardi, C.M. Treated municipal wastewater reuse in vegetable production. Agric. Water Manag. 2012, 104, 163-170. [CrossRef]

78. Disciglio, G.; Gatta, G.; Libutti, A.; Gagliardi, A.; Carlucci, A.; Lops, F.; Cibelli, F.; Tarantino, A. Effects of irrigation with treated agro-industrial wastewater on soil chemical characteristics and fungal populations during processing tomato crop cycle. J. Soil Sci. Plant Nutr. 2015, 15, 765-780. [CrossRef]

79. Tzortzakis, N.; Saridakis, C.; Chrysargyris, A. Treated Wastewater and Fertigation Applied for Greenhouse Tomato Cultivation Grown in Municipal Solid Waste Compost and Soil Mixtures. Sustain. 2020, 12, 4287. [CrossRef]

80. Akponikpè, P.I.; Wima, K.; Yacouba, H.; Mermoud, A. Reuse of domestic wastewater treated in macrophyte ponds to irrigate tomato and eggplant in semi-arid West-Africa: Benefits and risks. Agric. Water Manag. 2011, 98, 834-840. [CrossRef]

81. Akhtar, N.; Inam, A.; Inam, A.; Khan, N.A. Effects of city wastewater on the characteristics of wheat with varying doses of nitrogen, phosphorus, and potassium. Recent Res. Sci. Technol. 2012, 4, 18-29.

82. Pedrero, F.; Camposeo, S.; Pace, B.; Cefola, M.; Vivaldi, G.A. Use of reclaimed wastewater on fruit quality of nectarine in Southern Italy. Agric. Water Manag. 2018, 203, 186-192. [CrossRef]

83. Psarras, G.; Chartzoulakis, K.; Kasapakis, I.; Kloppmann, W. Effect of different irrigation techniques and water qualities on yield, fruit quality and health risks of tomato plants. Acta Hortic. 2014, 1038, 601-608. [CrossRef]

84. Li, P.; Qi, X.-B.; Du, Z.-J.; Hu, C.; Guo, W. Effect of reclaimed municipal wastewater irrigation on greenhouse soil mineral nitrogen dynamic and fruit quality of tomato. In Proceedings of the 2nd Annual International Conference on Energy, Environmental \& Sustainable Ecosystem Development (EESED 2016), Kunming, China, 26-28 August 2016.

85. Beneduce, L.; Gatta, G.; Bevilacqua, A.; Libutti, A.; Tarantino, E.; Bellucci, M.; Troiano, E.; Spano, G. Impact of the reusing of food manufacturing wastewater for irrigation in a closed system on the microbiological quality of the food crops. Int. J. Food Microbiol. 2017, 260, 51-58. [CrossRef] [PubMed]

86. Marouelli, W.A.; Silva, W.L.C. Water tension thresholds for processing tomatoes under drip irrigation in Central Brazil. Irrig. Sci. 2007, 25, 411-418. [CrossRef]

87. Favati, F.; Lovelli, S.; Galgano, F.; Miccolis, V.; Di Tommaso, T.; Candido, V. Processing tomato quality as affected by irrigation scheduling. Sci. Hortic. 2009, 122, 562-571. [CrossRef]

88. Demir, A.D.; Sahin, U. Effects of different irrigation practices using treated wastewater on tomato yields, quality, water productivity, and soil and fruit mineral contents. Environ. Sci. Pollut. Res. 2017, 24, 24856-24879. [CrossRef] [PubMed]

89. Liang, J.; Zhang, J.; Wong, M.H. Effects of air-filled soil porosity and aeration on the initiation and growth of secondary roots of maize (Zea mays). Plant Soil 1996, 186, 245-254. [CrossRef]

90. Wang, Z.; Liu, F.; Kang, S.; Jensen, C.R. Alternate partial root-zone drying irrigation improves nitrogen nutrition in maize (Zea mays L.) leaves. Environ. Exp. Bot. 2012, 75, 36-40. [CrossRef]

91. Bin Qi, X.; Huang, Z.D.; Qiao, D.M.; Li, P.; Zhao, Z.J.; Fan, T.; Wu, H.Q.; Fan, X.Y.; Hu, C.; Zhu, D.H.; et al. Effect of New Irrigation Technology on the Physiology and Water Use Efficiency of Potato by Reclaimed Water Irrigation. Adv. Mater. Res. 2013, 726-731, 3035-3039.

92. Ghanbari, A.; Abedi, K.J.; Taie, S.J. Effect of municipal wastewater irrigation on yield and quality of wheat and some soil properties in sistan zone. J. Sci. Technol. Agric. Nat. Resour. 2012, 10, 513-528.

93. GhassemiSahebi, F.; Mohammadrezapour, O.; Delbari, M.; KhasheiSiuki, A.; Ritzema, H.; Cherati, A. Effect of utilization of treated wastewater and seawater with Clinoptilolite-Zeolite on yield and yield components of sorghum. Agric. Water Manag. 2020, 234, 106117. [CrossRef]

94. Tabatabaei, S.-H.; Nourmahnad, N.; Kermani, S.G.; Najafi, P.; Heidarpour, M. Urban wastewater reuse in agriculture for irrigation in arid and semi-arid regions-A review. Int. J. Recycl. Org. Waste Agric. 2020, 9, 193-220.

95. Jacobs, J.; Rigby, S.; McKenzie, F.; Ryan, M.; Ward, G.; Burch, S. Effect of nitrogen on pasture yield and quality for silage in Western Victoria. In Proceedings of the Australian Agronomy Conference, Perth, Australia, 25-29 September 1989; pp. 24-29.

96. Ozbahce, A.; Tari, A.F. Effects of different emitter space and water stress on yield and quality of processing tomato under semi-arid climate conditions. Agric. Water Manag. 2010, 97, 1405-1410. [CrossRef] 
97. Kramer, P.J. Problems in Water Relations of Plants and Cells. Int. Rev. Cytol. 1983, 85, 253-286.

98. Johnstone, P.; Hartz, T.; Le Strange, M.; Nunez, J.; Miyao, E. Managing Fruit Soluble Solids with Late-season Deficit Irrigation in Drip-irrigated Processing Tomato Production. Hort. Sci. 2005, 40, 1857-1861. [CrossRef] 